\title{
The Beginnings of Maritime Travel
}

\author{
Robert G. Bednarik \\ International Federation of Rock Art Organizations (IFRAO), Melbourne, Australia \\ Email: robertbednarik@hotmail.com
}

Received 26 September 2014; revised 22 October 2014; accepted 18 November 2014

Copyright () 2014 by author and Scientific Research Publishing Inc.

This work is licensed under the Creative Commons Attribution International License (CC BY).

http://creativecommons.org/licenses/by/4.0/

(c) (i) Open Access

\begin{abstract}
Navigation of the sea is shown to have commenced in the order of one million years ago. The earliest evidence for it appears to be that available from Nusa Tenggara, Indonesia, but seafarers colonized also numerous other islands and one continent during the Pleistocene. These early technological feats of hominins provide a reliable measure of their technological limits, and indirectly about their cognitive faculties as well. To explore these aspects, the First Mariners Project conducts numerous experiments, some of which are briefly described in this paper. The implications of its findings for the first colonization of the Americas are also considered.
\end{abstract}

\section{Keywords}

Maritime Navigation, Pleistocene, Indonesia, Mediterranean, America, Replicative Experimentation

\section{Introduction}

The maritime history of humanity commenced not a few thousand years ago, as traditional nautical archaeology has tended to assume, but more than a hundred times as long ago (Sondaar et al., 1994; Bednarik, 1997, 1999a; Brumm et al., 2010). Archaeological data from Wallacea (Indonesia) have shown that the history of seafaring began in the late part of the Early Pleistocene, at least 900 ka (900,000 years) ago. To understand better the technological magnitude of these very early maritime accomplishments, expeditions are currently engaged in a series of replicative experiments. This paper examines the theoretical conditions of these experiments and demonstrates that hominin cognitive and cultural evolution during the Middle and early Late Pleistocene has been severely misjudged. The navigational feats of Pleistocene seafarers include, besides the earliest Indonesian evidence, also various crossings in the Mediterranean, near Japan, on the west coast of North America, and the first colonization of the Australian continent. In comparison to the usual discussions of the beginnings of maritime history, the ages of some of these early feats of the Paleolithic period are of an entirely different order of magnitude. 
Seafaring in the Pleistocene has been demonstrated by several types of finds from about twenty islands that have never been connected to a mainland (most of them not even to another island), or at least not during the Pleistocene; and from the continent of Australia (Bednarik, 2003). They consist of skeletal remains of approximately 200 humans, mostly from Australia but including those of nine individuals from four islands (Santa Rosa, Okinawa, Crete and Sardinia); and of human occupation evidence in the form of stone tools, food remains, ornaments, rock art, foot prints, and campsites. The two main regions of Pleistocene maritime navigation evidence are the Mediterranean, where at least half a dozen deep-water islands were occupied during the Ice Age, and the general region of eastern Asia to Australia. The only other island with known Pleistocene occupation is Santa Rosa, one of the Californian Channel Islands.

The earliest Mediterranean evidence, Clactonian stone tools found in Sardinia, is thought to be in the order of 300 ka old (Bini et al., 1993). Because it consists of surface finds, some commentators tend to discount it (e.g. Simmons, 2014). However, one cave site has provided a single bone of Homo erectus, our evolutionary predecessor (Ginesu et al., 2003). The islands of Crete and Gavdos were occupied by hominins at least since the Acheulian, as evidenced by numerous handaxes and other stone tools (Mortensen, 2008; Kopaka \& Matzanas, 2009; Strasser et al., 2010, 2011), evidence that is generally accepted. Cyprus, also never connected to the mainland during human existence, was settled toward the end of the Pleistocene (Simmons, 2014), as very probably were several other Mediterranean islands. By far the most extensive and the oldest proof of seafaring, however, comes from Indonesia, where this technology was first developed in the order of a million years ago. Evidence of hominin occupation of the late Lower Pleistocene and Middle Pleistocene is now available from three islands of Nusa Tenggara, formerly called the Lesser Sunda Islands: Flores (Verhoeven, 1958; Maringer \& Verhoeven, 1970; Sondaar et al., 1994; Morwood et al., 1998), Roti (Bednarik, 1999a) and Timor (Bednarik \& Kuckenburg, 1999). The early stone tools of Flores have been shown to be up to 840 ka old by a variety of dating methods, including fission-track dating, paleomagnetism, geology, paleontology, and the presence of datable tektites. Some of the strata containing these finds of stone tools and, in the case of Timor, charred animal remains are overlain by substantial facies of solid Quaternary rock, in places of more than 150 meters thickness (Bednarik, 2003). Their great age is therefore beyond dispute, irrespective of the comprehensive scientific dating evidence.

The presence of Homo erectus is thus amply demonstrated in Nusa Tenggara. It is the only human species known to have existed at that time. These islands form part of Wallacea, many of the tens of thousands of islands between Asia and Australia/New Guinea. This region is named after Alfred Russel Wallace, the 19th century British naturalist who discovered the almost complete absence of Asian mammals on these islands and correctly deduced that this fauna never had the opportunity of colonizing them (Wallace, 1890). The Wallace Line is in fact the most important biogeographical barrier or filter in the world. It runs between Bali, which at the lower sea levels of the Pleistocene was connected to Asia via Java and Sumatra, and Lombok, the first of the islands that were never part of any other landmass. Indeed, all of these islands are geologically very young, having been formed as the Australian plate slid under the Asian plate in the late Tertiary. They are only a few million years old (Figure 1).

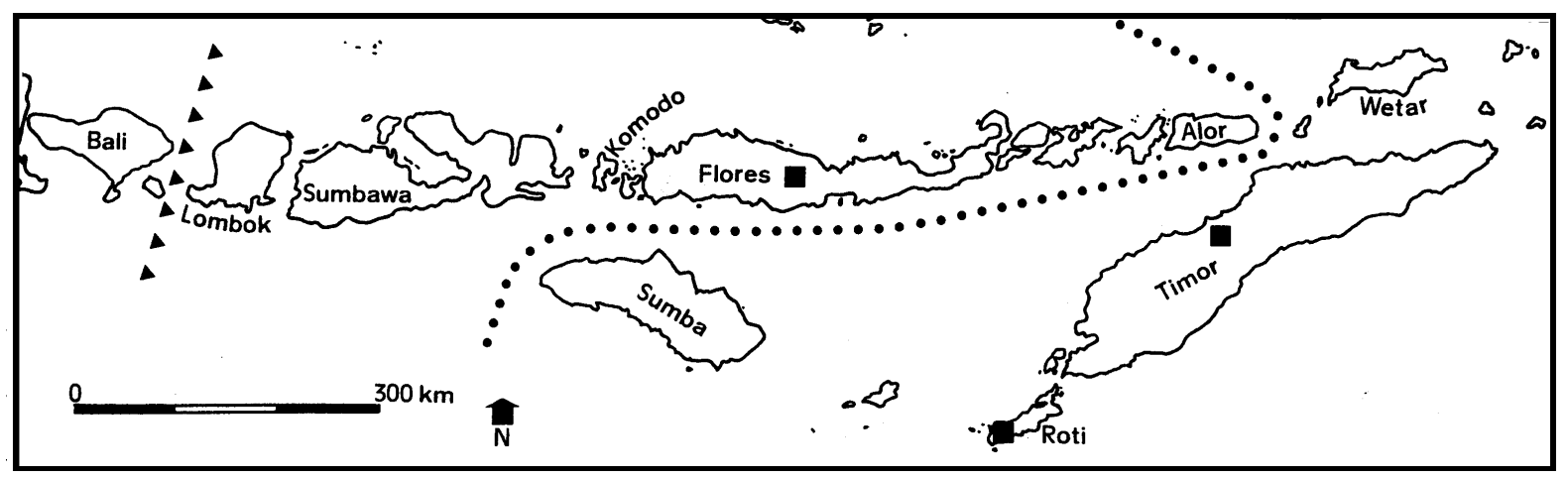

Figure 1. Map of Nusa Tenggara, Indonesia, showing the Wallace Line, the presumed boundary between the Sunda and Sahul tectonic plates, and the three locations that have yielded late Lower and Middle Pleistocene evidence of occupation by hominins. 
To reach Flores, human colonizers had to first cross to Lombok, from there to Sumbawa, and thence via Komodo to Flores. These crossings demanded the use of watercraft, particularly as each had to be completed by a genetically viable breeding population including an adequate number of females. In all cases the opposite shores were clearly visible from the shore of departure - at any sea level of the Ice Age period.

The first journey to Australia, however, occurred significantly later, possibly about 60 ka ago (Roberts et al., 1993). Almost certainly, this great delay is due to the fact that Australia has never been visible from Timor or Roti. The north of this continent is comparatively flat, and especially the very wide continental shelf facing Timor, which was exposed during periods of low sea level, had no elevations of much more than 100 meters height (Bednarik \& Kuckenburg, 1999). Consequently the shore became only visible after about nine-tenths of the distance from Timor had been crossed. This does not mean, however, that the Pleistocene inhabitants of Timor could not know the presence of a large landmass to their south. They would have experienced mariners, attuned to recognizing indirect evidence of land. For instance smoke of large bushfires, which may rise several kilometers into the air, would have been visible occasionally, and in the tropics typical cumulus cloud formations often develop over land, especially during afternoons. In addition, Pleistocene mariners would have observed the directions of sea currents, prevailing wave direction and the seasonal or migratory movements of birds and sea creatures, such as tortoises. The crossing to Australia was therefore probably delayed for many hundreds of millennia because it demanded a developed symbolic tradition capable of placing sufficient trust in the conscious judgment of signs to accept the risks involved in sailing to an unseen destination.

The first seafarers can thus be assumed to have been enticed by visual contact with the target shore, and this seems to have been an essential precondition for attempting maritime colonization until well into the Late Pleistocene. This applied to all of the known crossings that occurred prior to the first landfall of Australia. The actual distances to be journeyed in each case are not readily known, because the time the crossings first occurred is not precisely known, and the exact sea levels at these times remain speculative. Moreover, the elasticity of the Earth's crust and the processes of isostatic compensation is a variable which is difficult to account for with precision, and the high incidence of tectonic adjustments in the general region of Indonesia throughout the late Tertiary and the entire Quaternary with its attendant frequent vulcanism would resist any simplistic modelling. It is therefore much safer to speculate about sea distances by determining which large land eutherians had managed to breach the sea barrier in question. By far the best maritime colonizers are elephants (capable of swimming 50 $\mathrm{km}$ and probably more), followed by hippos (20 km) (Bednarik \& Kuckenburg, 1999). Deer, bears, tapirs and pigs, although excellent swimmers, only manage considerably shorter sea distances of 5 to $15 \mathrm{~km}$ (particularly under adverse maritime conditions), even though they and other genera taking to the water readily occurred in Pleistocene Southeast Asia. Small species (rodents, lizards, snakes etc.) are not relevant here; their ability to raft on floating vegetation for long periods is well known (Diamond, 1977).

Various species of proboscideans crossed to numerous islands of Wallacea and the Philippines where they experienced speciation and dwarfism in many separate developments (Hooijer, 1957; Verhoeven, 1964; Groves, 1976; Bednarik, 1999a; Bednarik \& Kuckenburg, 1999). Elephants are superb long-distance swimmers, having been observed to swim for 48 hours in herd formation across African lakes, and in one reported case swimming a distance of $48 \mathrm{~km}$ at sea and in another at a speed of $2.7 \mathrm{~km} / \mathrm{h}$ (Johnson, 1980). Their buoyancy is helped by digestive gases in their intestines and their habit of travelling as a herd would facilitate the success of a founding population upon landfall. On this basis it is a reasonable assumption that the distance between Bali and Lombok, or anywhere along the Wallace Line, was never much less than $30 \mathrm{~km}$, i.e. similar to that of today. Humans were the only other large mammals to cross these sea barriers, but they do not cross water barriers in herd formation by swimming, nor do they possess trunks or digestive gases to assist buoyancy. If it were possible to cross sea straits on mats of floating vegetation, as one archaeologist has claimed, other large species would have done the same, so this is not a viable interpretation either. Moreover, the crossings had to be undertaken by sufficient numbers of people, especially fertile females, to found a genetically viable population. Without this, no colonization event could possibly lead to the archaeological visibility of the resulting island people. For instance the density and number of excavated stone artifacts in the dozen or so excavated sites in the Soa Basin of Flores demonstrates the presence of a large, thriving human population by the end of the Early Pleistocene. Consequently there is only one possible explanation of the evidence: humans developed the ability to construct watercraft very significantly earlier than has hitherto been considered possible.

This explanation is supported by the numerous subsequent Pleistocene colonizations of islands, by that of Australia, and probably even by the first entry into Europe, which is more likely to have been via the Strait of 
Gibraltar than from Asia (Bednarik, 1999b).

\section{Rationale of Maritime Experiments}

In much the same fashion as we can use the absence or presence of certain species on deep-water islands to formulate tentative propositions about the former distances of sea to be crossed to reach them, we can also use the demonstrated capability of humans to cross sea barriers to estimate their technological capabilities at a given point in time. This approach of determining levels of technological competence is new in archaeology, and it promises much better resolution than the traditional approach of basing such assumptions on the contents of refuse deposits. In the same way as the maximal capabilities of modern society, such as space travel, are unlikely to be reflected by the debris found in our garbage dumps, this is a much more precise way of fathoming the past.

Begun in 1996, the First Mariners Project described here has made its task precisely to determine the minimum preconditions under which colonizing parties would have been capable of crossing specific sea barriers. Since we know roughly at what time these crossings were first accomplished, this should then tell us what the people concerned were capable of - not only in a technological sense (resources, tools, techniques), but also in a cognitive and cultural sense. The skills necessary for such feats cannot be passed on genetically; they need to be conveyed culturally (culture referring here to the non-genetic transfer of practice; Handwerker, 1989). To do so, certain prerequisites are essential in the case of maritime navigation skills. To determine what these were is an integral part of cognitive archaeology.

Obviously this kind of study demands extensive replication experiments. These need to include the design and construction of the most primitive sea-going vessels by which the crossing in question is achievable. Such experiments produce not, strictly speaking, true replicas, because we cannot know what the vessels in question were like. Nevertheless, by using in the construction of such watercraft the materials and tools available at the time and in the region, the range of possibilities is narrowed down very considerably. Moreover, the rationale of the experiments is not so much to establish how a crossing can succeed, but to determine the practical limits of how it would be possible — by instead finding out at what level it would fail. This approach mirrors the principle of falsification, the basis of modern science, and for this reason alone it is a scientific procedure.

Such a program of replication must also include a great many further experiments. For instance, it needs to be shown how drinking water can be carried on sea journeys, and on longer trips how the sailors can carry or obtain sustenance. Obviously one would expect them to be accomplished fishermen, otherwise they would presumably not have developed navigational skills in the first place (O'Connor et al., 2011). To replicate the way they would have fed themselves at sea one needs to establish how to make harpoon points of types known to have been used at certain times in human history, using the tools then available. This is only one example and many other such replicative experiments copying artefacts of the time assist greatly in securing an understanding of available technologies. They need to cover all aspects of procuring, curating, treating, storing, working, and using the materials known to have been in use at the time. Such materials might include bamboo, wood, bark, vines, fibers, wax, resins, bone, stone, skins, and leaves or palm fronds.

This renders the experiments underpinning the research into earliest seafaring very complex indeed. The principal tools to be used in all these related activities - from preparing the tools for fire-making by friction (Figure 2)

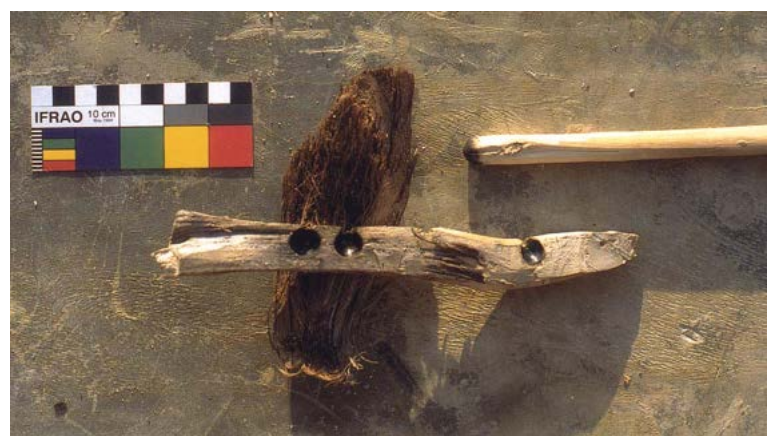

Figure 2. Fire drill used for lighting fires on the Nale Tasih 1 expedition. 
to setting tools in resins, to splicing cordage of split forest vines and making wooden paddles —are stone artefacts of the period in question. For crossing the sea barriers within Indonesia, to Sardinia, or the Strait of Gibraltar, the tool models have to be stone artefacts of the Lower Paleolithic. For the crossings to Australia, Okinawa and several other Mediterranean islands, Middle Paleolithic tools would have been used, and replicas of them must be the basis of any such experimentation.

\section{The Replication Experiments}

Based on these rationales, the largest project ever undertaken in replicative archaeology was commenced in 1996. It consists of almost countless experiments conducted under controlled conditions, from the production of stone tools to the construction of many simple but seagoing rafts. An integral part of this extensive program is to study the results and by-products of many work processes, such as microscopic wear traces on stone tools used exclusively for specific tasks. The highlights of the project, however, are the sea-trials of completed vessels, and the attempts in some cases to cross specific sea barriers.

So far, the First Mariners Project has constructed eight sea-going vessels, six in Indonesia and two in Morocco. Of these, two were models to test technologies, six were used to attempt full-scale crossings, of which four were completed successfully and two failed. The story of this venture is not just a scientific adventure in the finest tradition, it has generated a knowledge base about Pleistocene seafaring that did not exist at all before. The use of sea-going rafts faded out about a hundred years ago in Indonesia, before detailed observations were made of the effectiveness of the relevant technology (Hornell, 1946; Ling, 1956, 1970; Doran, 1971, 1978). It now has to be re-learnt, starting from its most basic aspects.

The first "replica” of a Pleistocene vessel, built with stone tools in late 1997 and early 1998, was launched in Roti on 14 February 1998 (Bednarik, 1998). Sea trials were commenced on 6 March and showed a number of design shortcomings and material defects, and in combination with unfavorable wind and current conditions caused by the El Niño phenomenon, this led to the abandonment of the attempt to sail the 15-ton raft with a crew of eleven to Australia. The 23-m Nale Tasih 1 was returned to Roti and on 9 March was beached at Oeseli for examination and destructive testing. It was dismantled down to every single component (Figure 3), material samples were tested, and one pontoon was sectioned by chainsaw to remove a 30-cm sample, to check the performance of various bamboo species and the effects of water penetration. As a result of infestation by bamboo beetles, and to a lesser degree through cracking, 93\% of the air chambers were found to contain some water. The tensile strength of some of the plant fibers used as cordage was found to have been severely reduced by seawater (Bednarik \& Kuckenburg, 1999).

On the basis of these findings, a radically different, simpler design was adopted for Nale Tasih 2, an 18-m bamboo raft of only 3.6 tons. Construction of this vessel began in August 1998 near Kupang, West Timor, and the primitive raft was launched in mid-November. On 17 December it left Kupang with a crew of five (Bednarik \& Kuckenburg, 1999). The raft had been constructed entirely from materials available to Middle Paleolithic people of Indonesia: bamboo, rattan forest vines, hand-made gemuti ropes of palm fiber, teak wood, lontar pipa string, and palm leaves, especially of the lontar palm. On board were two mangrove logs, hollowed out by termites and sealed off with wood, beeswax, bark, and tree resin, and containing 350 liters of drinking water. The A-frame mast bore a 24-square meter sail made from palm fiber (Figure 4). The Nale Tasih 2 was well equipped with spare parts, including two sails, a steering oar, vines, ropes, and other cordage, and to effect repairs it carried 65 stone artifacts, replicas of Middle Paleolithic types made from black sedimentary silica stone.

Food provisions included 30 half-ripe coconuts, several bundles of bananas, a basket of mangoes, some melons and cassava, salted meat, a basket of pottok (native millet of Roti), palm sugar, salt, and a few limes. However, these were supplementary supplies, it was intended to derive most food from the sea. For this purpose the raft was equipped with several harpoons and fish spears. It also carried a firebox of wood, filled with sand and three heating stones of limestone, plus firewood and coconut husks. Fire was made with a fire drill, consisting of a hand-operated hardwood drill and a softwood base. Utensils were made from coconut shells, and buckets from folded lontar palm leaves. Food was cooked in such containers.

The Nale Tasih 2 travelled without an escort boat, it had no radio, and the crew's only contact with the outside world was via a satellite telephone, only twice a day to preserve battery power. With the exception of this item, and equipment for navigation, recording and scientific purposes, all gear and supplies would have been available to sailors $60 \mathrm{ka}$ ago. The experimental raft reached the continental shelf of Australia, which formed the 


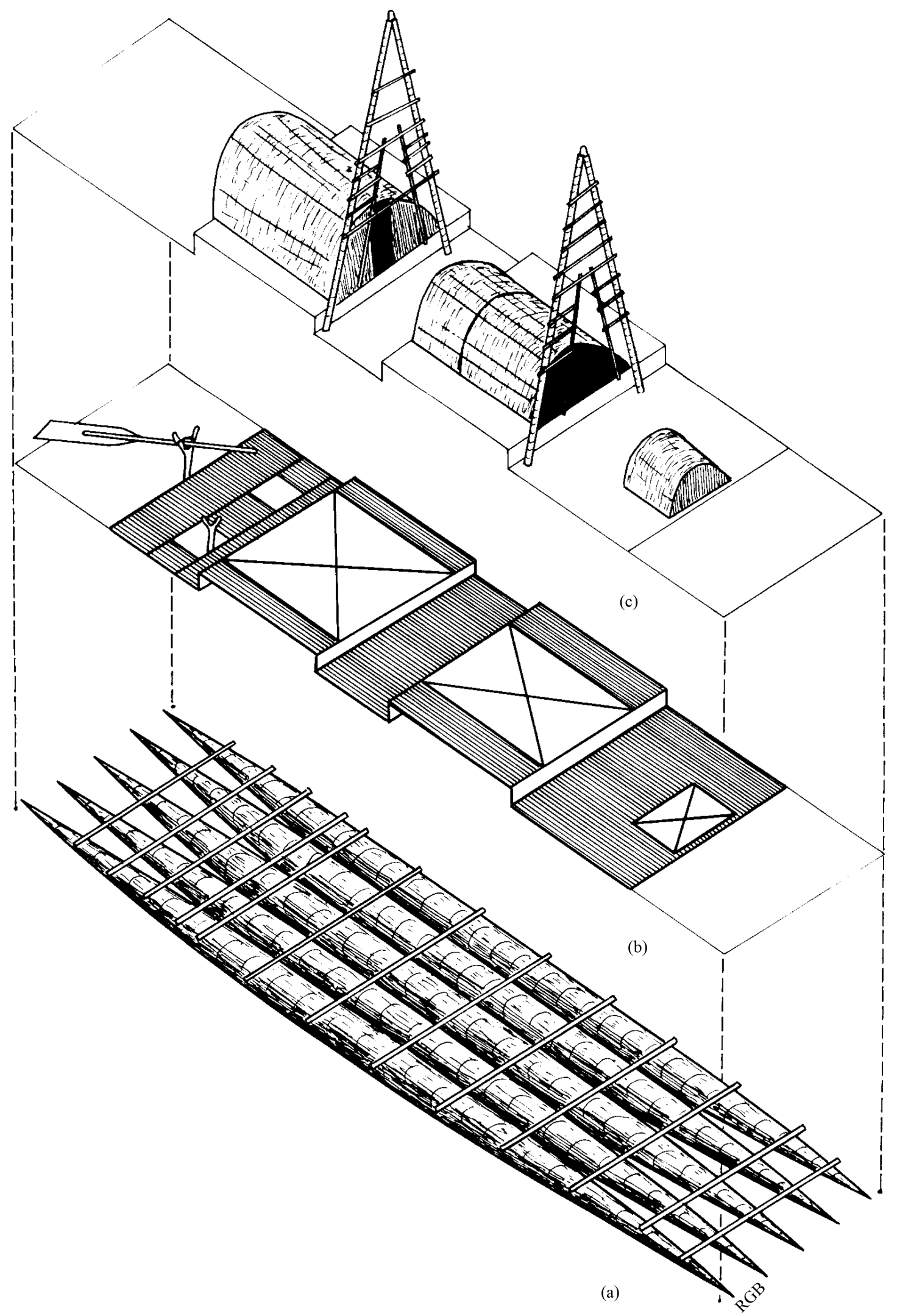

Figure 3. Exploded view of the 15-ton bamboo raft Nale Tasih 1: (a) pontoons, (b) decking, (c) superstructures. 


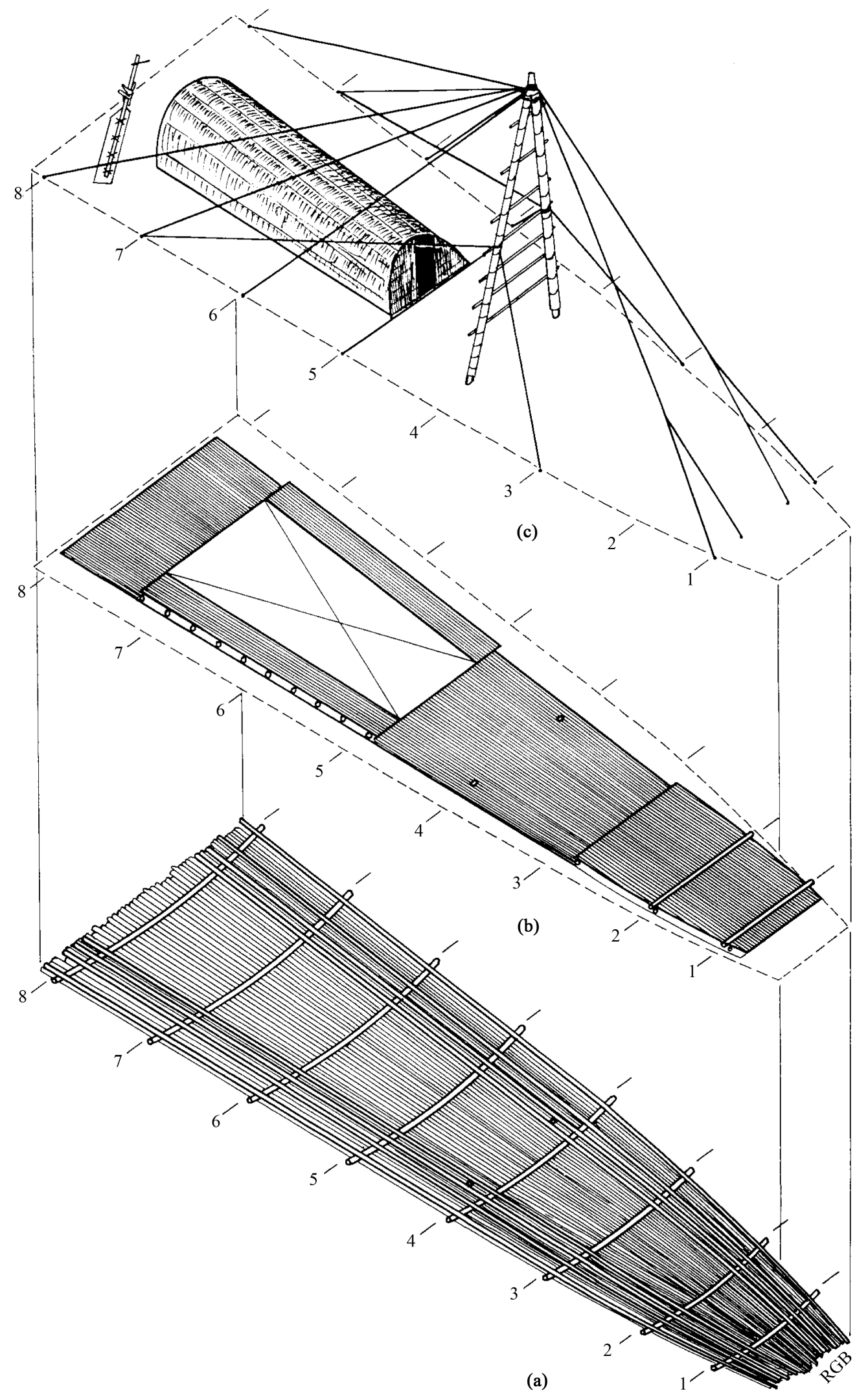

Figure 4. Exploded view of the 3.6-ton bamboo raft Nale Tasih 2: (a) raft, (b) decking, (c) superstructures. 
continent's shore 60 ka ago, after six days, thus having completed its primary objective. To gain more knowledge in its handling, the crew continued on toward Darwin. On the eleventh day, the seas became rough and the raft was sailed under extreme conditions for two days (Figure 5). The steering oar broke; a yard broke in two, and at one stage, all forward guy ropes of the mast snapped in unison, which created a dangerous situation. However, all repairs were effected successfully. On the thirteenth day, rough seas of 4 - 5-meter waves forced the raft towards Melville Island, north of Darwin (Bednarik \& Kuckenburg, 1999).

Of particular interest to the First Mariners Project is the question how the presumed first sea crossing in human history, from Bali to Lombok, was accomplished. It occurred well before 840 ka ago, quite probably up to a million years ago. The Nale Tasih 3 was an 11.4-metre long bamboo raft propelled by six oars (Bednarik, 2001a). Two days after it was launched at Padangbai in Bali, it was towed to the island's easternmost point, Pula Giliselang. On 23 March 1999, six oarsmen tried to row the simple platform to Lombok, over $35 \mathrm{~km}$ away. The vessel made excellent progress east initially, peaking at 3.2 knots, but as it entered the deep-water channel, over $1300 \mathrm{~m}$ deep here, its northward drift in a strong current proved irresistible. Every effort was made to row against the current, but after about six hours it became evident that we would inevitably miss the northwestern corner of Lombok. The attempt was abandoned under appalling weather conditions, about $15 \mathrm{~km}$ from the nearest Lombok coast.

A second attempt was made in the following year (Bednarik, 2001a). A simple platform of 29 stalks of bamboo, held together by six thwart timbers, was equipped with twelve wooden paddles, laboriously carved with primitive stone tools. The preferred material for lashings was split rattan (Calamus sp.), although hand-made gemuti cordage was used for non-crucial fastenings. Rattan lashings were made by stripping the vines with stone flakes, and other stone tools were used throughout construction. The Nale Tasih 4 set out from Pula Gilibiaha, south of Amlapura, on 31 January 2000. Twelve carefully chosen paddlers commenced the marathon effort of paddling continuously all day. Initial progress was superb, with a consistent speed above 3 knots, peaking at 4.2 knots, and maintaining the planned eastern course well. However, once the depth exceeded $1000 \mathrm{~m}$, the raft entered waters of choppy condition and waves of $1.5 \mathrm{~m}$, with a distinct current. The current's strength increased and at times the vessel remained essentially stationary, despite enthusiastic efforts by the crew to overcome it. Most of the crew experienced episodes of severe fatigue; one of us collapsed unconsciously and remained in a coma for days. The northerly drift became impossible to counter, threatening failure of this attempt only about 7 $\mathrm{km}$ from Pula Trewangan, the nearest of the Gillies. However, closer to the shore the current subsided and the coast was reached twelve hours after commencement. We had paddled continuously and strenuously for an entire day, covering a distance of just under $51 \mathrm{~km}$ (Figure 6).

This experiment showed that it was possible for a simple platform to be paddled across Lombok Strait— - but only just. Two further rafts were built by the First Mariners Project at Ksar Seghir, east of Tangier, Morocco, on a beach facing Spain across the Strait of Gibraltar. One was a pontoon raft made from cane, the other consisted of inflated animal skins (Bednarik, 2001b). Both were constructed entirely with stone tools of Lower Paleolithic types of the time when Europe was first settled by humans from Africa. Lashings consisted of strips of split green cane and thongs made from animal skins. Once completed, both these rafts were also tested at sea but no attempt was made to cross to Spain. These were merely experiments to test different designs and materials.

A more recent experiment sought to establish the minimum material requirements of bringing ten people from Sumbawa to Komodo (the latter island was joined to Flores during periods of lower Pleistocene sea levels), using the means available to Lower Paleolithic hominins (Bednarik, 2007). This crossing of Sape Strait took place in October 2004. The Rangki Papa ("Father of all Rafts"), as the Sumbawese crew members called the bamboo raft, embodied all that had by then been learnt about seagoing rafts, and it performed superbly. Nevertheless, the powerful transverse currents prevented reaching the western coast of the target land, despite calm and favorable conditions. Notwithstanding all efforts to maintain an easterly course, the vessel drifted south to the open sea and could reach Komodo only by sheltering from the current below the southwestern corner of that island, on the lee of the ramparts of Pula Lankoi (Figure 7). The spiral course enforced by this maneuver meant that the raft travelled 36.4 kilometers to make landfall, demanding a great physical effort from its ten paddlers. This demonstrated again how impossible it must have been, at any time, to cross a narrow strait without an effective propellant. Such island hopping cannot be accomplished by mere drifting, be it on a vessel or on naturally accumulated vegetation matter-at least not in a reasonable time span. Such sea crossings were only possible for small animals, such as rodents, lizards, snakes, and insects, capable of living on drifts for periods of months and years, in the same way as many types of plant seeds are capable of surviving at sea. Such natural drifts can travel 


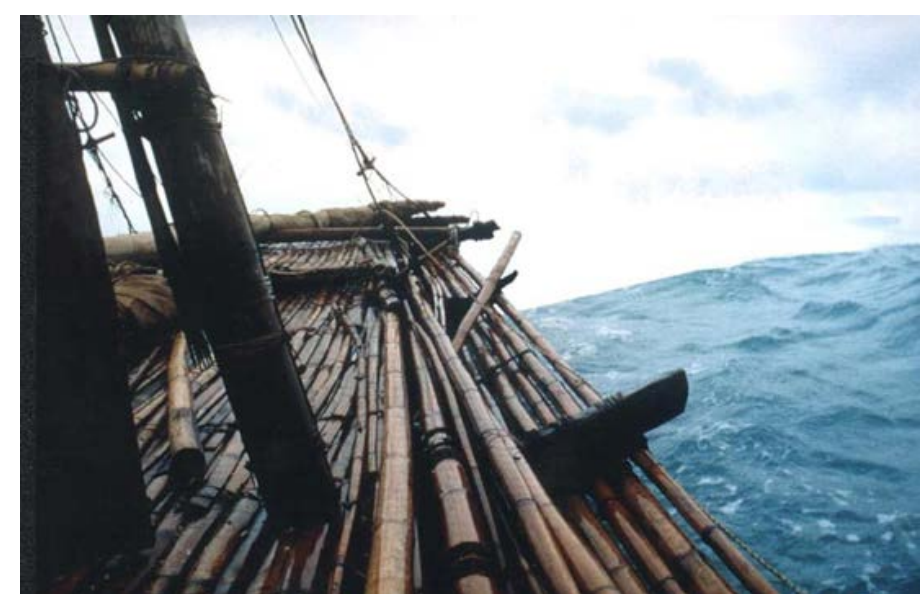

Figure 5. The Nale Tasih 2 travelling in heavy seas near Darwin, its bow projecting about $5 \mathrm{~m}$ above the wave.

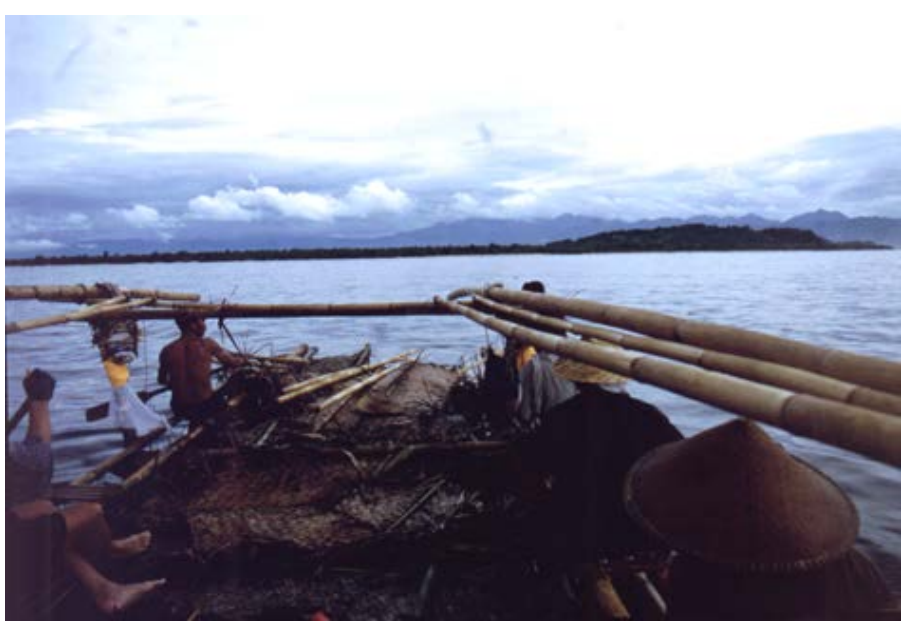

Figure 6. The 1.2-ton Nale Tasih 4 approaching Pula Trewangan, off the west coast of Lombok.

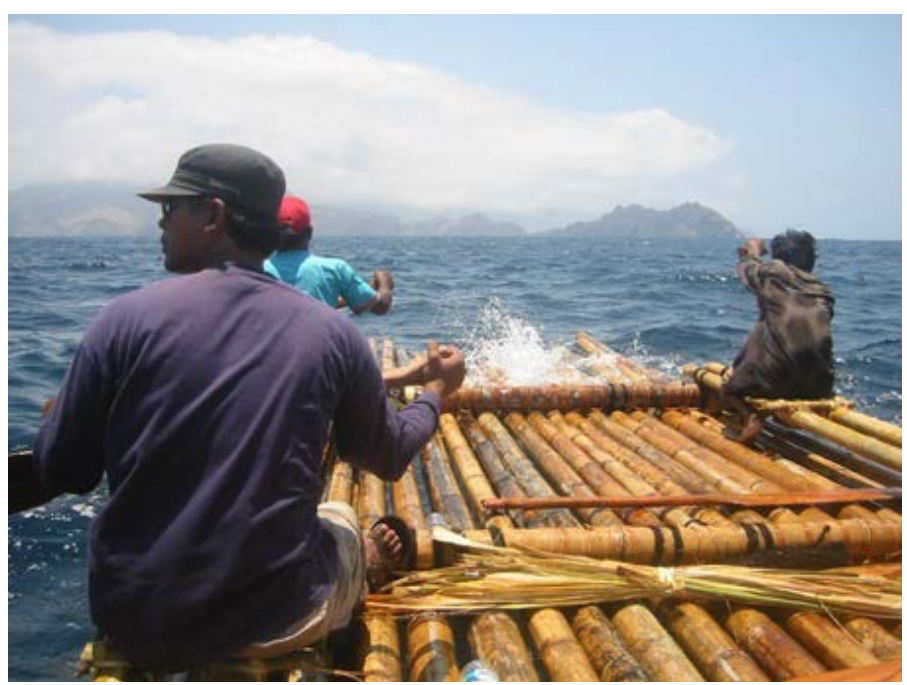

Figure 7. The 1-ton Ranggi Papa approaching Pula Lankoi, the southwestern corner of Lombok. 
great distances, but as already Wallace noticed, they cannot support larger mammals, which explains their absence in Wallacea.

The most recent major experiment of the First Mariners Project was an attempt to cross the remaining water barrier, Ales Strait, which separates Lombok from Sumbawa. The 13.6-m-long Lombok was the best designed, best performing raft of the project so far, the product of years of systematic studies. In defiance of expert advice, it was constructed from 24 green (uncured) bamboo stalks; indeed, throughout the project most academic expert advice had been found to be flawed, whereas that of local fishermen and traditional boat-builders was validated by the replication experiments. The four thwart timbers were of thick bamboo rather than wood; the bindings of about $700 \mathrm{~m}$ split calamus vine and $700 \mathrm{~m}$ tali ijuk, a hand-made rope from lontar palm fibre; and the paddles were of the superb timber of the bayur tree (Pterospermum acerifolium). On 5 March 2008, a handpicked crew of eight set out from north of Labuhanhai, crossing the strait north of Pulau Dua and reaching the bay north of Tanung Belusun in the excellent time of under 6 hours. But with the beach only $300 \mathrm{~m}$ away, a maelstrom turned the vessel around and it raced at 20 or 30 knots back west, forced by an irresistible current. As the weather deteriorated the crew tried desperately for the next 5 hours to land further south, before barely succeeding at last. Once again, the treacherous nature of currents in narrows was demonstrated graphically. The superbly performing raft was then towed to Flores for further sea trials (Figure 8).

\section{Discussion}

This project is to continue for several more years but some distinctive trends are already apparent. These patterns suggest that the distances travelled by hominins increased gradually over time, as did the severity of other obstacles mastered (Figure 9). By about a million years ago we can assume that the first use of navigation had emerged in the area of Java and Bali, probably to exploit offshore fishing grounds. This led to the ability of crossing perhaps over $30 \mathrm{~km}$ of water with colonizing groups. By $840 \mathrm{ka}$ before the present, at least three such sea barriers had been breached and Flores had an archaeologically highly visible population of Homo erectus. Perhaps around the same time, Acheulian mariners from northwestern Africa managed to cross to Gibraltar, a distance of only between 10 and $14 \mathrm{~km}$, while the Indonesian sailors eventually conquered a distance of between 60 and $100 \mathrm{~km}$, from Alor to Timor.

Much more development was required before humans were ready to cross to the unseen land of Sahul, which involved an actual distance of at least $200 \mathrm{~km}$ (the direct distance to the continental shelf is not relevant, because crossing along the shortest route would have always been impossible). This occurred much more recently, probably in the order of $60 \mathrm{ka}$ ago. But by 30 to $27 \mathrm{ka}$ before the present, distances in excess of $100 \mathrm{~km}$ were crossed frequently, and often to quite small islands, even in both directions. These included Gebe Island, New Ireland, Buka Island, and the Mone Bello Islands. Similar maritime capabilities had developed in the Mediterranean during the Late Pleistocene, when first Crete and Gavdos (Kopaka \& Matzanas, 2009) were colonized, followed much later by Cyprus. By that time, seafaring would have still involved very high risks, but the settlement

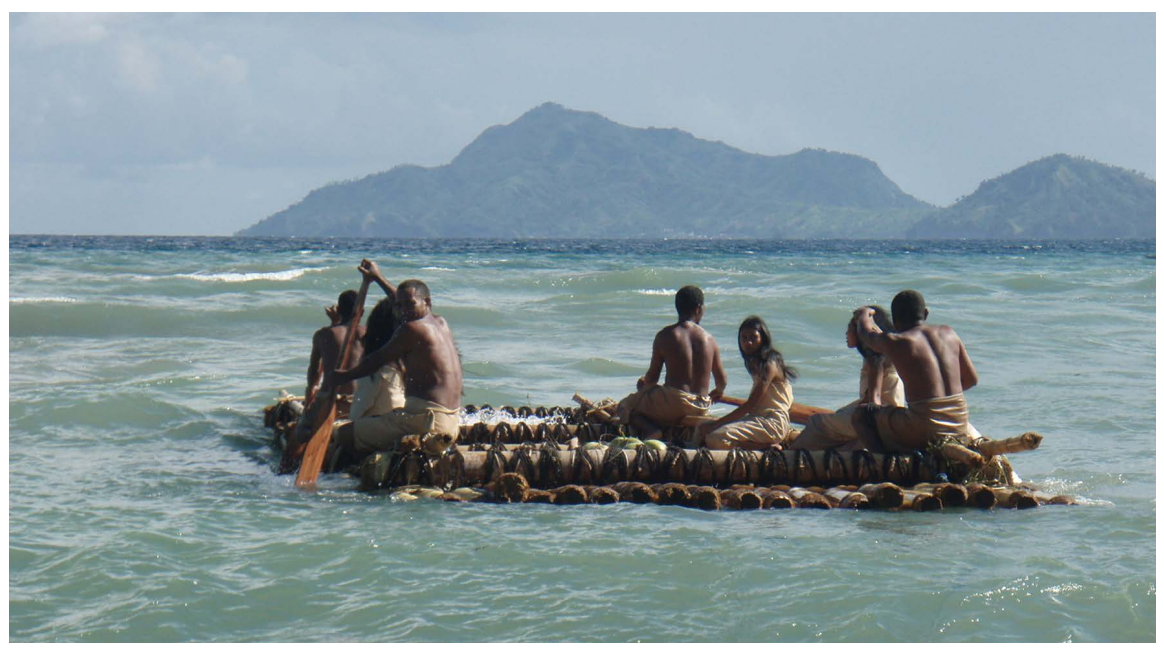

Figure 8. Sea trials of the Lombok near the south coast of Flores, 14 April 2008. 


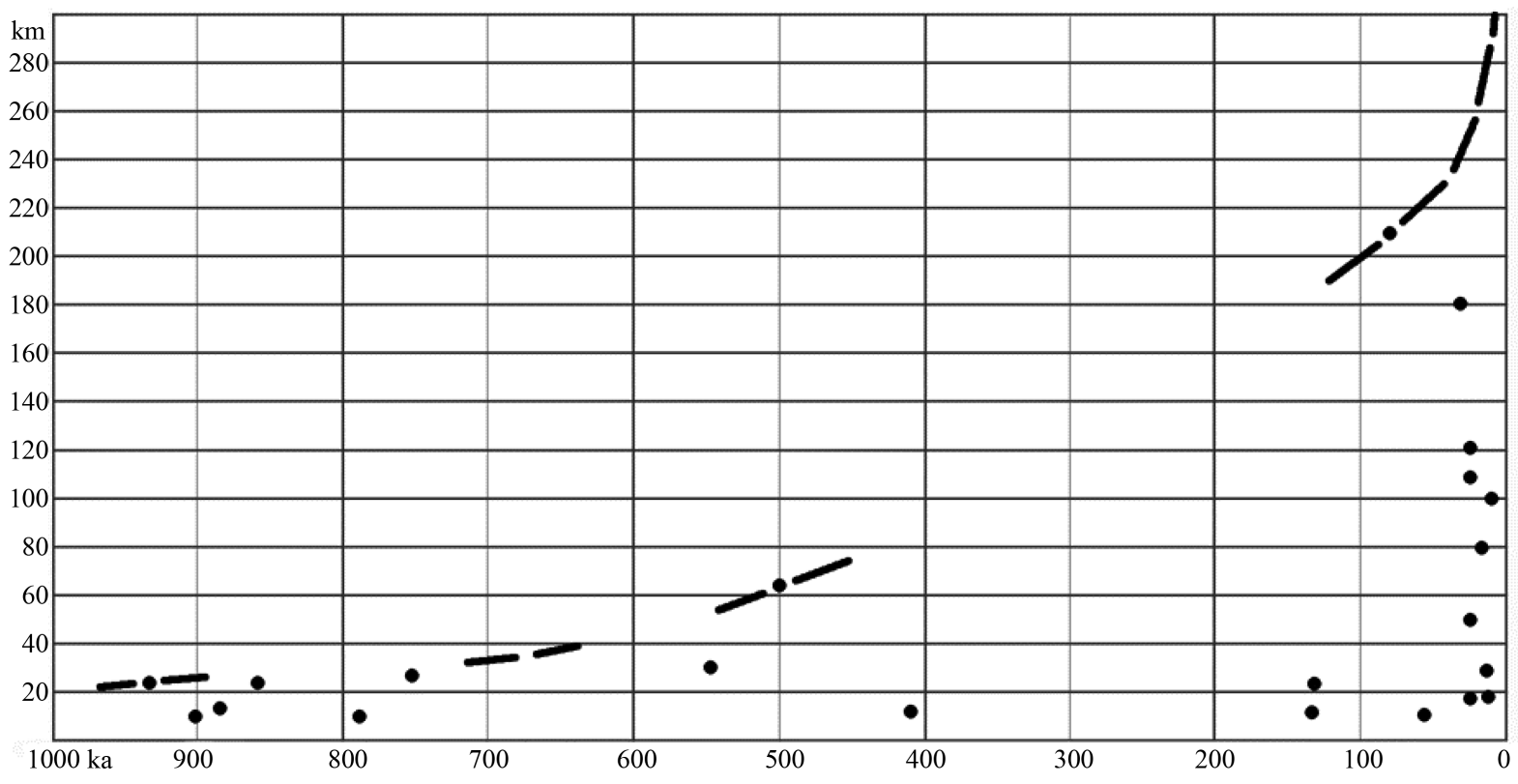

Figure 9. Estimated time of first maritime colonizations (in ka, millennia) plotted against presumed shore distances (not travel distances) at time of travel, showing how distances travelled increased gradually through time. The broken line thus indicates approximate maximal navigation capability of humans through time.

of around twenty islands that we know of (and no doubt others where we have yet to look) suggests that maritime navigation had reached the level of taking calculated risks. While it was now well developed in two world regions and spreading to others, the most sophisticated tradition remained that of the area to the north of Australia, eventually extending further into the Pacific, and it probably remained the most developed maritime technology in the world until modern history.

From the perspective of the earliest colonization of the Americas, a major impediment is the lack of consensus agreement concerning the timing of first human settlement of the New World. It is widely thought that east Asian settlers first crossed Beringia toward the end of the Pleistocene. On the basis of the above their technology can be safely assumed to have included seaworthy watercraft, and there is no need to postulate the use of a land-bridge. Indeed, if the current credible evidence reflects the true circumstances, it is possible that initial colonization was largely limited to the western coastal margin now under the sea, which would point to a primarily maritime population. Many North American archaeologists reject any pre-13 ka BP occupation evidence and the issue remains controversial (Dillehay \& Collins, 1988; Bednarik, 1989; Jelinek, 1992), while occupation evidence of greater age has been presented from South America (Bednarik, 1989). Niède Guidon (1986), Fabio Parenti (1993), and others have argued persuasively that human occupation in north-eastern Brazil extends back about 40 - 50 ka. The sandstone shelter Pedra Furada in Piauí has yielded a series of fifty-four radiocarbon dates from occupation horizons with many stone implements. The dates are stratigraphically consistent and if the hypothesis that the Americas were occupied via an Alaskan bridgehead were correct, the South American Pleistocene archaeological finds from Brazil, Venezuela, Peru, Argentina and Chile would suggest that humans must have reached North America somewhat earlier (Bednarik, 1989). The circumstances of this colonization remain entirely unknown and archaeology has consistently failed to produce any widely acceptable evidence of such early human presence in North America. The type of evidence offered includes that from such sites such as Calico in California, which in reality contains not a single stone implement below the uppermost few centimeters of its massive sediments; China Lake, also in California, which lacks a stratigraphic context for its two flake tools; and Old Crow in Yukon, with its inadequately dated bone artefact. Meadowcroft Rockshelter at perhaps up to 19 ka BP still falls short of the South American evidence. The Valsequillo site complex near Puebla, Mexico, remains thoroughly controversial.

It has therefore been suggested that the initial colonization of North America was restricted largely to coastal corridors, with only low population densities further inland (Bednarik 1989). Rapid expansion along the western coast by an essentially coastal people could have facilitated the settlement of South America. The erasure of 
now submerged coastal evidence might help explain the pattern in the empirical data. Globally there is a complete lack of direct Pleistocene evidence for coastal navigation, and very little about exploitation of marine environments, coastal settlement patterns and marine ecologies of the Ice Age. In the Old World this massive hiatus has resulted in a completely distorted picture of Pleistocene societies, with a heavy emphasis on inland ecologies and economies. The oldest direct evidence for the use of watercraft we have is all from the early Mesolithic of Europe, 8000 to 9500 years old (Bednarik, 1999a, 2003). Beyond this time, the present coasts of the world were all at higher elevations, continuously for perhaps $60 \mathrm{ka}$, and it is not likely that boats, rafts, oars, or paddles were frequently taken to such elevations, let alone would have survived there. The two human femora fragments and one humerus from Arlington Springs on Santa Rosa Island, off California (reportedly 13 ka old), demonstrate that around the time the most conservative archaeologists believe human occupation commenced in North America, people were certainly undertaking maritime travel in the region. Perhaps the first chapter of human presence in the New World still remains to be written, and it needs to be dedicated to mariners.

\section{References}

Bednarik, R. G. (1989). On the Pleistocene Settlement of South America. Antiquity, 63, 101-111.

Bednarik, R. G. (1997). The Earliest Evidence of Ocean Navigation. International Journal of Nautical Archaeology, 26, 183-191. http://dx.doi.org/10.1111/j.1095-9270.1997.tb01331.x

Bednarik, R. G. (1998). An Experiment in Pleistocene Seafaring. International Journal of Nautical Archaeology, 27, 139149. http://dx.doi.org/10.1111/j.1095-9270.1998.tb00797.x

Bednarik, R. G. (1999a). Maritime Navigation in the Lower and Middle Palaeolithic. Comptes Rendus de l'Académie des Sciences Paris, 328, 559-563.

Bednarik, R. G. (1999b). Pleistocene Seafaring in the Mediterranean. Anthropologie, 37, 275-282.

Bednarik, R. G. (2001a). Replicating the First Known Sea Travel by Humans: The Lower Pleistocene Crossing of Lombok Strait. Human Evolution, 16, 229-242. http://dx.doi.org/10.1007/BF02437414

Bednarik, R. G. (2001b). The Origins of Pleistocene Navigation in the Mediterranean: Initial Replicative Experimentation. Journal of Iberian Archaeology, 3, 11-24.

Bednarik, R. G. (2003). Seafaring in the Pleistocene. Cambridge Archaeological Journal, 13, 41-66. http://dx.doi.org/10.1017/S0959774303000039

Bednarik, R. G. (2007). Experimental Crossing from Sumbawa to Komodo by Bamboo Raft. INA Quarterly, 34, $13-17$.

Bednarik, R. G. (2014). The First Mariners. New Delhi: Research Press India.

Bednarik, R. G., \& Kuckenburg, M. (1999). Nale Tasih: Eine Floßfahrt in Die Steinzeit. Stuttgart: Jan Thorbecke Verlag.

Bini, C., Martini, F., Pitzalis, G., \& Ulzega, A. (1993). Sa Coa de Sa Multa e Sa Pedrosa Pantallinu: Due "Paleosuperfici” Clactoniane in Sardegna. Atti della XXX Riunione Scientifica, "Paleosuperfici del Pleistocene e del Primo Olicene in Italia, Processi si Formazione e Interpretazione”, Venosa ed Isernia, 26-29 Ottobre 1991, Firenze: Istituto Italiano di Preistoria e Protostoria, 179-197.

Brumm, A., Jensen, G. M., Van den Bergh, G. D., Morwood, M. J., Kurniawan, I., Aziz, F., \& Storey, M. (2010). Hominins on Flores, Indonesia, by One Million Years Ago. Nature, 464, 748-752. http://dx.doi.org/10.1038/nature08844

Diamond, J. M. (1977). Distributional Strategies. In J. Allen, J. Golson, \& R. Jones (Eds.), Sunda and Sahul: Prehistoric Studies in South-East Asia, Melanesia and Australia (pp. 295-316). London: Academic Press.

Dillehay, T. D., \& Collins, M. B. (1988). Early Cultural Evidence from Monte Verde in Chile. Nature, 332, 150-152. http://dx.doi.org/10.1038/332150a0

Doran, E. (1971). The Sailing Raft as a Great Tradition. In C. L. Riley, J. C. Kelley, C. W. Pennington, \& R. L. Rands (Eds.), Man across the Sea: Problems of Pre-Columbian Contacts (pp. 115-138). Austin: University of Texas Press.

Doran, E. (1978). Seaworthiness of Sailing Rafts. Anthropological Journal of Canada, 16, 17-22.

Ginesu, S., Sias, S., \& Cordy, J. M. (2003). Morphological Evolution of the Nurighe Cave (Logudoro, Northern Sardinia, Italy) and the Presence of Man: First Results. Geografica Fisica e Dinamica Quaternaria, 26, 41-48.

Groves, C. P. (1976). The Origin of the Mammalian Fauna of Sulawesi (Celebes). Zeitschrift für Säugetierkunde, 41, 201216.

Guidon, N., \& Delibrias, G. (1986). Carbon-14 Dates Point to Man in the Americas 32,000 Years Ago. Nature, 321, $769-771$. http://dx.doi.org/10.1038/321769a0

Handwerker, W. P. (1989). The Origins and Evolution of Culture. American Anthropologist, 91, 313-326. http://dx.doi.org/10.1525/aa.1989.91.2.02a00020 
Hooijer, D. A. (1957). A Stegodon from Flores. Treubia, 24, 119-128.

Hornell, J. (1946). Water Transport: Origins and Early Evolution. Cambridge: Cambridge University Press.

Jelinek, A. J. (1992). Perspectives from the Old World on the habitation of the New. American Antiquity, 57, 345-347. http://dx.doi.org/10.2307/280740

Johnson, D. L. (1980). Problems in the Land Vertebrate Zoogeography of Certain Islands and the Swimming Powers of Elephants. Journal of Biogeography, 7, 383-398. http://dx.doi.org/10.2307/2844657

Kopaka, K., \& Matzanas, C. (2009). Palaeolithic Industries from the Island of Gavdos, near Neighbour to Crete in Greece. Antiquity, 83. http://antiquity.ac.uk/projgall/kopaka321/

Ling, S.-S. (1956). Formosan Sea-Going Raft and Its Origin in Ancient China. Bulletin of the Institute of Ethnology, Academica Sinica, 1, 1-54.

Ling, S.-S. (1970). A Study of the Raft, Outrigger, Double and Deck Canoes of Ancient China, the Pacific and the Indian Oceans. Taipei: Institute of Ethnology, Academia Sinica.

Maringer, J., \& Verhoeven, T. (1970). Die Steinartefakte aus der Stegodon-Fossilschicht von Mengeruda auf Flores, Indonesien. Anthropos, 65, 229-247.

Mortensen, P. (2008). Lower to Middle Palaeolithic Artefacts from Loutró on the South Coast of Crete. Antiquity, 82. http://www.antiquity.ac.uk/projgall/mortensen/

Morwood, M. J., O’Sullivan, P. B., Aziz, F., \& Raza, A. (1998). Fission-Track Ages of Stone Tools and Fossils on the East Indonesian Island of Flores. Nature, 392, 173-176. http://dx.doi.org/10.1038/32401

O’Connor, S., Ono, R., \& Clarkson, C. (2011). Pelagic Fishing at 42,000 Years before the Present and the Maritime Skills of Modern Humans. Science, 334, 1117-1121. http://dx.doi.org/10.1126/science.1207703

Parenti, F. (1993). Le Gisement Préhistorique du Pléistocène Supérieur de Pedra Furada (Piauí, Brésil). Considérations Chronostratigraphiques et Implications Paléoanthropologiques. Documents Laboratoire Géologique Lyon, 125, 303-313.

Roberts, R. G., Jones, R., \& Smith, M. A. (1993). Optical Dating at Deaf Adder Gorge, Northern Territory, Indicates Human Occupation between 53,000 and 60,000 Years Ago. Australian Archaeology, 37, 58-59.

Simmons, A. H. (2014). Stone Age Sailors: Paleolithic Seafaring in the Mediterranean. Walnut Creek, CA: Left Coast Press.

Sondaar, P. Y., Van den Bergh, G. D., Mubroto, B., Aziz, F., De Vos, J., \& Batu, U. L. (1994). Middle Pleistocene Faunal Turnover and Colonization of Flores (Indonesia) by Homo-Erectus. Comptes Rendus de l'Académie des Sciences Paris, 319, 1255-1262.

Strasser, T. F., Panagopoulou, E., Runnels, C. N., Murray, P. M., Thompson, N., Karkanas, P., McCoy, F. W., \& Wegmann, K. W. (2010). Stone Age Seafaring in the Mediterranean: Evidence from the Plakias Region for Lower Palaeolithic and Mesolithic Habitation of Crete. Hesperia, 79, 145-190. http://dx.doi.org/10.2972/hesp.79.2.145

Strasser, T. F., Runnels, C., Wegmann, K., Panagopoulou, E., McCoy, F., Digregorio, C., Karkanas, P., \& Thompson, N. (2011). Dating Palaeolithic Sites in Southwestern Crete, Greece. Journal of Quaternary Science, 26, 553-560. http://dx.doi.org/10.1002/jqs.1482

Verhoeven, T. (1958). Pleistozäne Funde in Flores. Anthropos, 53, 264-265.

Verhoeven, T. (1964). Stegodon-Fossilien auf der Insel Timor. Anthropos, 59, 634.

Wallace, A. R. (1890). The Malay Archipelago. London: Macmillan. 
Scientific Research Publishing (SCIRP) is one of the largest Open Access journal publishers. It is currently publishing more than 200 open access, online, peer-reviewed journals covering a wide range of academic disciplines. SCIRP serves the worldwide academic communities and contributes to the progress and application of science with its publication.

Other selected journals from SCIRP are listed as below. Submit your manuscript to us via either submit@scirp.org or Online Submission Portal.
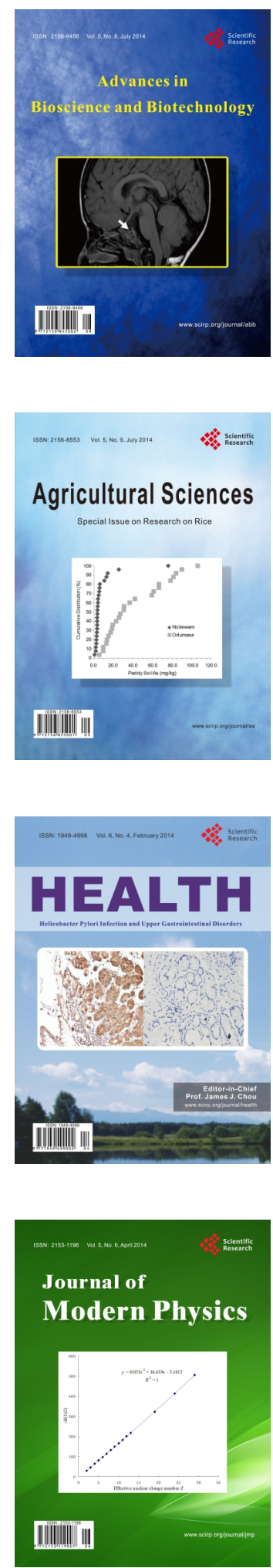
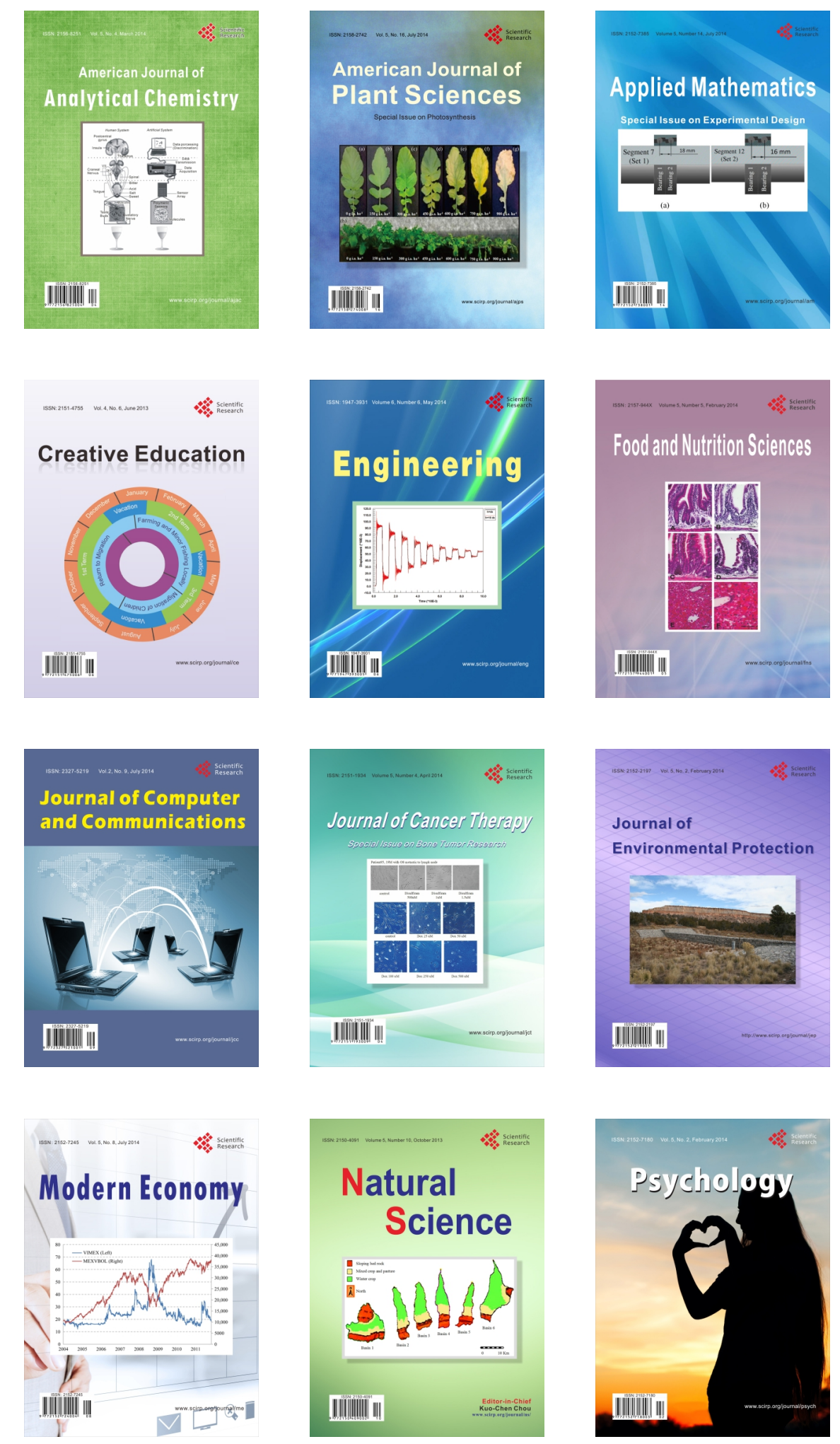